\title{
Comfort behaviour in harco strain of cockerels with different drinkers and at different periods of the day (short communication)
}

\begin{abstract}
Summary
The effects of different drinkers and time of the day on comfort behaviour was studied in two hundred and fiftytwo cockerels from week 4-8. The types of drinkers used were bamboo drinker (BD), clay pot drinkers (CD) and plastic fountain drinkers (FD). Comfort behaviour was observed in the morning and aftemoon and evening hours.

The largest number of total comfort behaviour observed during the four-week period was 3089 in $\mathrm{CD}_{\text {, followed }}$ by 2326 and 2216 in FD and BD respectively. Preening was the most frequently observed comfort behaviour, the average being $57 \%$ of the total comfort behaviour in all the groups, dust-bathing was the least observed, being on the average $6,0 \%$ in all the groups.

There was no significant effect of type of drinkers on comfort behaviour (acts/bird/hour). There was, however, a significant effect of time of day on comfort behaviour. The most comfort behaviour was performed in the afternoon being $35.5,39,5$ and 34.0 for $\mathrm{BD}, \mathrm{CD}$ and $\mathrm{FD}$ groups respectively. There was no difference in comfort behaviour (acts/bird/hour) in the moming and evenings being $26.6 \mathrm{vs} 28.32$ in the morning and evening, and 28.96 vs. 25.36 in the moming and evening for $\mathrm{CD}$ and FD groups respectively. However, the mean acts/bird/hour was significantly different in the morning and evening in BD group, being 23.5 vs. 27.96 for moming and evening respectively $(\mathrm{p} \leq 0.05)$.

There was a tendency of comfort acts/bird/20 $\mathrm{min}$. to increase with age, correlation coefficient being $0.23,0.85$ and 0.22 in BD, CD and FD groups respectively. There was, however, no significant effect of age of birds on comfort acts/bird/20 mins over the four-week period ( $p>0.05)$.
\end{abstract}

Key Words: drinker types, day-period, comfort behaviour, cockerels

\section{Zusammenfassung}

Titel der Arbeit: Wohlbefinden von Hähnchen untersucht an unterschiedlichen Verhaltensmerkmalen, Trănken und Tageszeiten (Kurzmitteilung)

Es wurde das Wohlbefinden an 250 Hăhnchen im Alter von 4 bis 8 Wochen an verschiedenen Verhaltenseigenschaften in drei Versuchsgruppen mit unterschiedlichen Tränkenformen untersucht. Als Kriterien des Wohlbefindens wurden die Zeiten für Staubbad, Federputzen, Kopfschutteln und -kratzen erfaß̧t. Der Vergleich von Benutzung von Bambus-, Tontopf- und Plastiktrănken ergab für die Gruppe mit Tontopftränken die stärkste Frequentierung. In allen Gruppen wurden die lăngsten Zeiten für das Federputzen, die geringsten fur das Staubbaden festgestellt. Zwischen den einzelnen Trănkenformgruppen ergaben sich jedoch keine signifikanten Unterschiede. Die größten Aktivitaten konnten am Nachmittag im Gegensatz zu den Morgen- und Abendstunden beobachtet werden, wobei im Versuchszeitraum fur alle Beobachtungen keine Abhängigkeit vom Alter der Tiere nachgewiesen werden konnte.

Schllisselwörter: Tränkentypen, Tageszeit, Wohlbefinden, Hăhnchen

\section{Introduction}

Information regarding the application of poultry behaviour to effective poultry management in Nigeria is very scarce, yet such information is needed to fully 
understand how birds fare in a variety of management practices currently in use. Much advancement in recent years has been witnessed in automation of poultry houses and birds are more or less forced to fit into designs rather than the design to meet the birds needs.

Comfort behaviours have been identified as behaviours that bird exhibit to enhance their comfort ability (MAULDIN, 1992). Observations have shown that the levels to which birds exhibit this behaviour are affected by the type of housing and the time of the day (TARNAKA and HURNIK, 1992).

It has also been observed that water is supplied to poultry in rural areas in a variety of containers, and since the poultry in the rural areas in Nigeria constitute about $80 \%$ of the national total (Adegbola, 1990) the welfare of the poultry in these areas will have a significant impact on the national flock. In such an uncontrolled environment to which birds are exposed in the tropics, the levels to which birds perform comfort behaviours at various times of the day need to be studied.

Accordingly, this study was designed to study the effect of different types of drinkers and at different times of the day on the comfort behaviour of poultry.

\section{Material and methods}

A total of two hundred and fifty-two four-weeks old cockerels of Harco strain were used for this study. They were brooded at the brooding house at Faculty of Agriculture, Obafemi Awolowo University premises. At day-old, birds were randomly assigned to three groups based on the type of drinkers used, namely the bamboo drinker (BD) group in which water was supplied in containers made from bamboo (Bambusa vulgaris). Group II was the clay pot (CD) group in which water was supplied in clay pots purchased from local pottery. Group III was the fountain drinker (FD) group in which water was supplied in conventional plastic fountain drinkers.

The birds were kept in a deep litter house in which environmental condition was subjected to diurnal pattern, the average temperature during the period of the experiment was $28.5 \mathrm{C}$ in the afternoon.

Behaviour observations were made on a daily basis in the morning at 0800 hours, afternoon at 1300 hours and evening at 1800 hours (all at GMT, GMT = Greenwich Mean Time)). At each observation period, when the observer entered the pens, the door were shut and the birds were given five minutes to adjust to the presence of the observer, Each replicate was then observed for 5 minutes anon records were kept for each occurrence of dust-bathing, preening, head shaking and head scratching as defined by MAULDIN (1992).

The data collected on behaviour was subjected to a two-way analysis of variance as outlined by SNEDECOR and COCHRAN (1966). Significance was tested at $p \leq 0.05$. New Duncan's multiple range test was used to separate the means that were significantly different (DUNCAN, 1955).

\section{Results}

Table I shows the total number of comfort behaviour observed during a 5-week period. Overall, the largest number of total comfort behaviour was observed in the CD group followed by FD and BD groups being 3089, 2326 and 2216 for $\mathrm{CD}, \mathrm{FD}$ and $\mathrm{BD}$ group respectively. Preening was the most frequently observed comfort behaviours in all the 
groups. Dust bathing was the least frequently observed behaviour, the average being $6.9 \%$ in all the groups. The occurrence of the comfort behaviours at different periods of the day did not follow a definite pattern. It appears, though, that the least occurrence of dust bathing occurred during the morning while the most occurred in the afternoon, except in the BD group where the greatest occurrences was in the evening. In all the groups, the most occurrence of head scratching was in the afternoon.

Table I

Total Comfort Behaviours (acts/bird/hour)*

\begin{tabular}{llllllllll}
\hline Behaviour & BD & \multicolumn{10}{c}{$\begin{array}{c}\text { GROUPS } \\
\text { CD }\end{array}$} \\
\hline & $\mathrm{M}$ & $\mathrm{A}$ & $\mathrm{E}$ & $\mathrm{M}$ & $\mathrm{A}$ & $\mathrm{E}$ & $\mathrm{M}$ & $\mathrm{A}$ & E \\
Dust Bathing & 22 & 49 & 64 & 69 & 145 & 86 & 25 & 62 & 32 \\
Preening & 368 & 425 & 484 & 637 & 643 & 587 & 490 & 391 & 374 \\
Head Shaking & 117 & 102 & 113 & 112 & 124 & 112 & 125 & 127 & 130 \\
Head Scratching & 151 & 171 & 150 & 176 & 195 & 167 & 183 & 213 & 184 \\
\hline Figures arc that of 28 birds; M-Morning: A-Afternoon; E-Evening
\end{tabular}

Table II shows the actual comfort acts/bird/hour in all the groups. There was no statistical significant effect of type of drinker on comfort acts/bird/hour $(p>0.05)$ ). There was, however, a statistically significant effect of time of day on comfort acts/bird/hour ( $\mathrm{p} \leq 0.05$ ) the greatest being performed in the afternoon, except in the CD and FD groups where comfort acts performed in the morning were not different from that observed in the evenings.

Table 2

Comfort Behaviour (acts/bird/hour)*

\begin{tabular}{llll}
\hline Period of Day & \multicolumn{3}{c}{ GROUPS } \\
\cline { 2 - 4 } & BD & CD & FD \\
\hline Morning & $23.50^{\mathrm{b}}$ & $26.60^{\mathrm{a}}$ & $28.96^{\mathrm{a}}$ \\
Afternoon & $35.50^{\mathrm{b}}$ & $39.50^{\mathrm{b}}$ & $34.00^{\mathrm{b}}$ \\
Evening & $27.96^{\mathrm{C}}$ & $28.32^{\mathrm{b}}$ & $25.36^{\mathrm{a}}$ \\
\hline Figures are means for 28 birds & & &
\end{tabular}

We Figures within the same column with different superscripts differ significantly $(p \leq 0,05)$

Table III shows the trend exhibited by birds in total comfort acts/bird/20 mins as the birds grew from 4 to 8 weeks of the life. There was an apparent tendency of comfort acts/bird/20 mins to increase with age, $\mathrm{r}$ being $0.23,0.85$ and 0.22 in $\mathrm{BD}, \mathrm{CD}$ and FD groups respectively. The regression coefficient (b) was $0.09,0.33$ and 0.09 in $\mathrm{BD}, \mathrm{CD}$ and FD groups respectively. The regression values were not statistically significant $(\mathrm{p}>0.05)$.

Table 3

Comfort Behaviour and Age (mean acts/bird/20 mins)*

\begin{tabular}{|c|c|c|c|}
\hline Age (week)** & $\mathrm{BD}$ & $\mathrm{CD}$ & FD \\
\hline I & 1.41 & 1.51 & 1.82 \\
\hline 2 & 2.61 & 1.75 & 2.96 \\
\hline 3 & 2.04 & 2.58 & 2.88 \\
\hline 4 & 1.88 & 2.33 & 2.16 \\
\hline$R$ & 0.23 & 0.85 & 0.22 \\
\hline b & 0.09 & 0.33 & 0.09 \\
\hline$Y=$ & $1.77+0.09 \mathrm{X}$ & $1.22+0.329 \mathrm{X}$ & $2.22+0.09 \mathrm{X}$ \\
\hline
\end{tabular}

Comfort acts/bird $/ 20$ mins not statistically significant $(\mathrm{p}>0.05):{ }^{\circ}$ Means are that of 28 birds; $* 0$ Weeks are counted forward from week 4 of
the birds. 
The prediction equations for comfort acts with age yield the following:

$$
\begin{aligned}
& \mathrm{Y}=1.77+0.09 \mathrm{X} \\
& \mathrm{Y}=1.22+0.329 \mathrm{X} \\
& \mathrm{Y}=2.22+0.09 \mathrm{X}
\end{aligned}
$$

For $\mathrm{BD}, \mathrm{CD}$ and FD groups respectively.

\section{Discussion}

The significant effect of the time of the day on comfort behaviour is consistent with observations in literature. Birds engaged in more comfort behaviour in the afternoon than morning and evening. TARNAKA and HURNIK (1992) drew the same conclusion. This might be associated with diurnal changes in temperature. During the afternoon, the temperature in the pens was on the average $30.5 \mathrm{C}$ which was $2 \mathrm{C}$ higher than in the morning. Evidently, birds at such higher temperature would be expected to engage more in comfort behaviour as this is a way of facilitating their comfort ability (MAULDIN, 1992). This observation has implication in birds housed either in cage or deep litter as used in this study. Observations have shown that bird performed more comfort behaviours in aviaries than in cages (ELSON, 1980; TARNAKA and HURNIK, 1992). This might be attributed to the fact that cages are unnatural to birds as compared to aviary. Thus, in hot tropical environment where environmental conditions of pens are largely uncontrolled, when birds are unable to engage in behaviour that facilitate their comfort during the unfavourable afternoon hours, this might have serious consequences on their growth performance and production.

There was a tendency for comfort acts to increase with age and then start to decline, Overall, as birds grew older, there was no significant effect of age on comfort behaviour ( $p>0.05$ ). Study of LEE and CRAIG (1981) did not include the age of birds per se, but they observed that social ranking had no significant effect on comfort behaviour like preening and grooming. This observation is of interest since birds fix themselves into social ranks as they grow older (SIEGEL, 1984; CRAIG, 1992) However, since social ranking which is a function of age of the birds had no significant effect on preening, this can lead to the conclusion that age of birds should have no significant effect on preening, Interestingly, preening constituted about $75 \%$ of the total comfort behaviours observed in this study.

From this study, the fact emerges that a study of behaviours in general, and comfort behaviour in particular is essential in effective management practice, a conclusion that was drawn by NICOL (1989) and ELSON (1990). This is especially so in the tropics where environmental temperature can rise to a level that is not comfortable for birds. Inability of birds in such situations to engage in comfort behaviours can have serious implications on their welfare.

\section{Acknowledgement}

The authors wish to acknowledge the support of Obafemi Awolowo University, Ile Ife in funding this as well as their other research works.

\section{References}

CRAIG, J.V.:

Application of Behaviour to Poultry Management. Poultry Sci. 71 (1992), 235-243 


\section{DUNCAN, D.B. :}

Multiple Range and Multiple F Test. Biometrics 11 (1955), 1-15

\section{ELSON, H.A.:}

Recent Developments in Laying Cages Designed to Improve Bird Welfare. World's Poultry Sci. Journal. 46 (1990), 34-37

LEE, Y; CRAIG, J.V.:

Evaluation of Egg-Laying Strains of Chickens in Different Housing Environments. Role of Genotype by Environment Interaction. Poultry Sci. 60 (1981), 1769-1789

\section{MAULDIN, J.M.:}

Applications of Behaviour to Poultry Management. Poultry Sci. 71 (1992), 634-642

NICOL, C.J.:

Social Influencies on the Comfort Behaviour of Laying Hens, App, Animal Behaviour Sci. 22 (1989), 75.81

SIEGEL, P.B. :

The Role of Behaviour in poultry Production. A Review of Research. Applied Animal Ethology. 11 (1984), 299-316

SNEDECOR, G.W.; COCHRAN, W.G.:

Statistical Methods. Iowa State University Press, Ames, Iowa, pp. 299-338, 1966

TARNAKA, T; HURNIK, J.F.:

Comparison of Behaviour and Performance of Laying Hens Housed in Battery Cages and Aviary. Poultry Sci. 71 (1992), 235-243

Reccived: 2000-08-17

Accepted: $2001-06-28$

Author's address

OLAJUMOKE C. DANIYAN Ph.D

Department of Animal Science

Faculty of Agriculture

Obafemi ^wolowo University

Ile Ife

Nigeria.

E-mail: sdaniyan(@iyahoo.com 
Buchbesprechung

BIOTECHNOLOGIES DE LA REPRODUCTION CHEZ LES MAMMIFERES ET LHOMME

ANNIK BOUROCHE-LACOMBE

1. Auflage, INRA Editions, RD 10, 78026 Versailles cedex, France, 200, 122 Seiten, 37 Abbildungen, davon 8 farbig, 3 Tabellen, ISBN 2-7380-0935-2, Preis: 41,16 EUR

Das Gebiet der Biotechnologie ist international durch eine sehr dynamische Entwicklung gekennzeichnet. Diese allgemeine Aussage trift in Sonderheit auch auf das Gebiet der Reproduktionsbiotechnologie zu. Mit dem Wörterbuch Biotechnologien der Reproduktion bei Süugern und beim Menschen werden über 200 Begriffe und einige ihrer Synonyme aufgefuhrt, in knapper Form, jedoch wissenschaftlich korrekt in franzosischer Sprache erläutert und anschließend in englischer Sprache zusammengefasst. Das Wörterbuch richtet sich weniger an die im Fachgebiet Tătigen als vielmehr an Studenten, aber auch an Nichtspezialisten, die Interesse an sicheren Informationen und Definitionen zum Fachgebiet haben. Dabei sollte berlicksichtigt werden, dass es mit Sicherheit nicht das Anliegen der Herausgeber war, die gesamte Begriffswelt von der kanstlichen Besamung bis zu den aktuellen Klonierungstechniken in einem Handbuch zu vereinen. Vielmehr wurden bei der Auswahl der Begriffe sowohl ausgewăhlte physiologische Grundlagen als auch spezifische Techniken berüksichtigt. Mehrere gut gestaltete Abbildungen geben zusătzliche Informationen zu den Sachverhalten. Da der Schwerpunkt auf der Erläuterung von Sachverhalten in franzosischer Sprache liegt und leider gegenuber vorherigen Schriften in dieser Reihe eine deutsche Fassung fehit, wird der Leserkreis in Deutschland begrenzt bleiben. Den Worterbuch nachgestellt sind (lber 80 weiterfuhrende Verweise auf franzðsische und ober 120 auf englischsprachige Fachliteratur sowie ein Register aller Begriffe in beiden Sprachen. Drucktechnisch aberzeugt das Wörterbuch durch eine klare Gliederung und leserfreundliche Hervorhebungen, Insgesamt kann das vorliegende Wörterbuch allen interessierten Lesern empfohlen werden. 